\title{
US reduces options on disposal of plutonium
}

Washington. The US Congress has killed the experimental Integral Fast Reactor (IFR) at the Argonne West National Laboratory, Idaho, reducing the likelihood that nuclear physics will play a role in disposing of the United States' plutonium stockpile.

Last week, a conference of House and Senate members agreed to eliminate $\$ 100$ million annual funding for the IFR. This will end work on actinide recycling, a technique aimed at reprocessing plutonium into a radioactive (and militarily useless) compound of heavy metals.

The technique was the most advanced of a set of ideas that had been proposed by nuclear physicists to deal with plutonium. But a recent report from the National Academy of Sciences concluded that its application was too distant to help deal with the immediate plutonium problem (see Nature 367, 307; 1994).

Furthermore, efforts by scientists at the
Los Alamos National Laboratory in New Mexico to promote a rival approach, using particle accelerators to destroy plutonium and long-living radioactive isotopes, appear unlikely to attract serious interest from the Department of Energy.

At the first international conference on so-called Accelerator Driven Transmutation Technology (ADTT), held in Las Vegas two weeks ago, Los Alamos announced a \$3 million research collaboration with Russia on the transmutation of plutonium.

But no high-level Department of Energy officials attended the meeting. And industry representatives said privately that the laboratory had little chance of securing the $\$ 500$ million it wants for an ADTT demonstrator. Around \$25 million - mostly from the nuclear weapons programme - has already been spent there on studies of the technology.

Charles Bowman, head of the ADTT office at Los Alamos, concedes that trying

\section{Allain freed - to face new charges}

Paris. Jean-Pierre Allain, the haematologist sentenced to four years' imprisonment (with two suspended) in 1992 in the French contaminated blood affair, was indicted last week on poisoning charges, less than 24 hours after a parole board had announced that he would be released the following day. He was eventually released on Monday evening.

A week earlier, the Paris Bar Association, prompted by the indictment - also on poisoning - of Michel Garretta, former director-general of the French National Transfusion Centre(CNTS), had warned the French legal system against letting public opinion override the law in its prosecution of individuals alleged to have supplied haemophiliacs with factor VIII contaminated with HIV in the mid1980s (see Nature 370, 319; 1994).

The timing of Allain's indictment has provoked similar widespread criticism. Le Monde described it as "the cruel image of a cat squashing a mouse with a blow of its claw after letting him think he was free", adding that the French legal system does not usually behave like this.

Despite the new charges pending, a court agreed on Monday to free Allain on parole. Among those waiting outside the courtroom was Robin Carrell, head of the department of haematology at the University of Cambridge - where Allain holds a faculty appointment — who has led an international campaign to prove Allain's innocence.

The court has said that one condition for Allain's freedom is that he should stay in France, and he will therefore be unable to return to Cambridge, where his post is being kept open. Carrell's campaign, and have sent letters of support to Allain. More than 30 Nobel prizewinners, for example, have written individually to President François Mitterrand to plead Allain's case.

Allain's wife, Helen Lee, who worked with him at CNTS, describes the new charges as a "nightmare". She is convinced her husband has been made a scapegoat to appease public opinion, and that the justice system has deliberately ignored evidence that he is innocent.

Indeed, Jean-Claude Gluckmann, professor of immunology at the PitiéSalpétrière Hospital in Paris, IMAGE submitted written evidence to Allain's appeal in 1993 stating that either Allain was innocent, or many others - including himself were also guilty. His memorandum Allain: now accused was ignored, he of 'poisoning'. says.

Lee accuses many other leading French AIDS experts and physicians of "hypocrisy" and "cowardice". She is particularly distressed that whereas many now declare they knew of the risks of HIV contamination in 1985, but that their warnings were ignored, quotations from the same individuals in newspapers from 1985 show that they, too, had failed to anticipate the danger. Declan Butler
Many scientists worldwide have backed to sell the technology to the National Academy study team, as well as to another group of scientists from the Department of Defense's (DoD)'s Jason Program who also reported unfavourably on it in January, has been "a challenge". "They say the technology isn't near enough to deployment to deal with present, urgent problems: we don't agree," says Bowman.

The Las Vegas meeting was an attempt to build public, as well as scientific, support for transmutation technology, which gained widespread publicity late last year with the endorsement of Carlo Rubbia, former director of CERN, the European Laboratory for Particle Physics (see Nature 366, 392; 1994).

"This is a programme whose time has come," says John Brown, a division director at Los Alamos. But, he adds, "these are very difficult times for new technological ideas. The public is sceptical about all technologies, not just this one."

ADTT would use a proton accelerator to bombard a target, creating enough neutrons to sustain fission in a subcritical nuclear reactor. Bowman says that the extra neutrons would enable the machine to keep on destroying undesirable fission products which would poison conventional nuclear reactors.

All of this would take place in a molten salt coolant-fuel which would be chemically recycled in a closed loop, ploughing plutonium and long half-life isotopes back in until they transmute, and therefore generating no long-lived nuclear waste.

This process would generate vast amounts of radiation from the short half-life isotopes produced. But Bowman thinks such radiation could be contained in the closed cycle, where separation would take place under remote control.

The physics of the process dictates that one transmuting power station would be needed to deal with the plutonium produced online by four existing nuclear power stations. A vast construction programme would therefore be needed to deal with new plutonium - as well as the backlog.

Despite these daunting obstacles, Carlo Rubbia describes the process as "a sensible proposal" which he said that scientists should be looking in to.

But, as Bowman concedes, the easiest thing to do with ADTT is to use it to make tritium for use in atom bombs. Now that the reactors which used to do this have been closed for safety reasons, the DoD needs such a facility to help maintain its 20,000 nuclear weapons.

The DoD is pressing for a speedy decision. Pete Domenici, the Republican Senator for New Mexico, also known as 'the Senator for Los Alamos,' wants it to be an accelerator-based facility, built at the weapons laboratory.

Colin Macilwain 